\title{
Mentally ill or chosen by spirits? 'Shamanic illness' and the revival of Kazakh traditional medicine in post-Soviet Kazakhstan
}

\section{Danuta Penkala-Gawęcka}

To cite this article: Danuta Penkala-Gawęcka (2013) Mentally ill or chosen by spirits? 'Shamanic illness' and the revival of Kazakh traditional medicine in post-Soviet Kazakhstan, Central Asian Survey, 32:1, 37-51, DOI: 10.1080/02634937.2013.771872

To link to this article: http://dx.doi.org/10.1080/02634937.2013.771872

曲 Published online: 01 Mar 2013.

Submit your article to this journal $[\pi$

Џll Article views: 358

Q View related articles $\longleftarrow$

Citing articles: 1 View citing articles $\square$ 


\title{
Mentally ill or chosen by spirits? 'Shamanic illness' and the revival of Kazakh traditional medicine in post-Soviet Kazakhstan
}

\author{
Danuta Penkala-Gawęcka*
}

Department of Ethnology and Cultural Anthropology, Adam Mickiewicz University, Poznań, Poland

\begin{abstract}
This article discusses spiritual healing in post-Soviet Kazakhstan with reference to changing discourses about 'shamanic illness': a condition that afflicts the future healer. What had traditionally been identified as the call of spirits was seized in the Soviet period by biomedical discourse which ascribed those symptoms to mental illness. Whereas this attitude also influenced popular understandings of 'shamanic illness' at the time, traditional ideas have been gradually restored in the context of the political and social changes of the 1990s. Biomedical discourse on 'shamanic illness' has also undergone significant changes. I argue that this was induced by multiple interconnected factors, among which are the reappraisal and support of the government for Kazakh 'folk' medicine as a part of the national heritage, and a favourable attitude to local, traditional forms of religiosity. This allowed for collaboration between doctors and healers in the context of institutionalization of traditional medicine. Alongside these influences the strength of the tradition of remembering the spirits of ancestors prompted the re-establishment of this core experience in the process of becoming a healer: the call of spirits.
\end{abstract}

Keywords: spiritual healing; shaman; shamanic illness; mental illness; post-Soviet Kazakhstan; Central Asia

Many researchers working in Central Asia, especially those interested in the 'revival' of Islam and broader questions of religious life, have noticed a surge of medical pluralism in the postSoviet period. There is an apparent multiplicity of healing methods that have developed since the collapse of the Soviet Union, and their relations with biomedicine are shaped by complex economic, social and political factors. This phenomenon is, however, understudied apart from a few anthropological works (Hohmann 2007, 2010b; Penkala-Gawecka 2002). More attention has been paid to spiritual healing, that is, healing with the help of spirits, ${ }^{1}$ which has been discussed mainly in the context of 'everyday Islam' as a part of what is locally perceived as 'Muslimness' (Kehl-Bodrogi 2008; Privratsky 2001; Rasanayagam 2006). Some researchers take other perspectives on this kind of healing, addressing the issues of its legitimization (Pelkmans 2005) or competition of healers in the market (Bellér-Hann 2001).

This article explores spiritual healing in the context of the vast field of medical pluralism in Kazakhstan. ${ }^{2}$ The changed political and economic circumstances in post-Soviet Central Asia influenced the efflorescence of spiritual healing which draws heavily on traditional beliefs and practices. I focus on a particular aspect - the so called 'shamanic illness' - which was traditionally perceived as a sign of predestination and a preliminary stage on the way to becoming a shaman. My purpose is to show changing perceptions of its symptoms that have led to a contemporary revalidation of its original meaning in popular and partly in biomedical discourses.

*Email: danagaw@amu.edu.pl 
I argued that the support of the government for Kazakh 'folk' medicine, treated as a part of national heritage, and nation-building policy significantly contributed to the rehabilitation of spiritual healing. In addition, the favourable official attitude to local forms of 'Muslimness' and the lively tradition of remembering the spirits of ancestors, helped to recover the traditional discourse on 'shamanic illness'. Nevertheless, other factors should also be taken into account, including the weak public health-care system that influenced the process of the institutionalization of traditional medicine, enabling close contacts between physicians and healers.

The text is based on in-depth fieldwork that I carried out in Kazakhstan during my five-year stay there between 1995 and 2000, mainly in Almaty and its vicinity. The main focus of my studies was complementary medicine set in its wider political and socio-economic context, as well as complementary practitioners - healers and doctors - and their patients. I collected ethnographic material in the course of many talks with spiritual healers, including shamans, and during observations of their séances in different settings.

\section{Traditional Kazakh shamans and 'shamanic illness'}

The healing practices of shamans were only a part of Kazakh medical traditions, which comprised various therapies practised by a range of specialists, like bone-setters (sinıqsh $)$, herbalists (däriger) or folk surgeons (otashı) who performed bloodletting and minor operations. In addition, methods used by täwips (from Arabic: tabib) consisted of elements of ArabicPersian-Tajik 'great medical tradition' (Unani) based on written transmission, which was, however, more popular in other parts of Central Asia (Penkala-Gawęcka 2009; Sharmanov and Atchabarov 1978).

Kazakh spiritual healing was practised mainly by shamans (baqsi) whose supernatural powers, purportedly enabled them to mediate between spirits and the human world. Veneration of ancestor spirits ( $\operatorname{ar} \bar{u} a q)$ was at the core of Kazakh spirituality and shaped their shamanic practices. The baqsi, usually a man, ${ }^{3}$ used various techniques aimed at expelling evil spirits with the assistance of his helping spirits (Basilov 1992, 146-154).

In addition to shamans, mullahs, ishans (Sufi shaykhs) and itinerant dervishes (düana) depended on contacts with the supernatural world in their healing. They recited verses from the Qur'an and prepared amulets (tumar) against harmful spirits and the evil eye. Like shamans, they were known for their skills in curing mental disorders through exorcisms. ${ }^{4}$ The process of Islamization of the Kazakh shamanic performances was already well advanced in the late nineteenth and early twentieth centuries. Besides ancestral spirits they invoked Muslim saints and Allah, and included prayers from the Qur'an in their healing. The shamanic séance was called oyın (play) or zikir (from Arabic dhikr) - the last term used for ecstatic performances in Sufi brotherhoods. As DeWeese $(1994,51,54)$ points out, these facts may be taken not only as the evidence of Islamization of the earlier local beliefs and practices, but also as indigenization of Islam which assimilated those traditions and granted them reaffirmation.

A traditional way of becoming a shaman in Central Asia involved a kind of rite of passage which started with an episode of 'shamanic illness', 5 often described in ethnographic reports. It included strange dreams and visions, unusual behaviours and persistent suffering of the afflicted. It should be stressed that those symptoms were differentiated from madness or other mental disorders that, in local perceptions, required the intervention of the healer. The initiation experiences usually induced separation of an afflicted individual from the community and were often accompanied by serious physical ailments like loss of sight or paralysis. 
That particular condition was easily recognizable in the past. Shamanic abilities could be transmitted from a former shaman to someone who belonged to the next generation or to the generation of their grandchildren. However, the call of spirits was crucial and a person chosen by the ancestor spirits ( $a r \bar{u} a q$ ) was obliged to accept their gift. When after the shaman's death one of his descendants fell seriously ill, it was taken as a sign given by the spirits (Basilov 1992, 128-129; Toleubaev 1997), clear both to the future baqsi and to all members of the community. Put in another way, within the traditional frame just getting ill with specific symptoms elicited recognition of this suffering as the call of spirits and entering the liminal phase of the rite of passage. The process to follow could last quite a long time and during that stage a candidate was taught and tried by spirits. The change of status was marked then by a blessing received from spirits and sometimes from an older, experienced shaman or a respected religious man.

\section{Attitudes to shamans and other traditional healers during Russian and Soviet times}

It is significant that many reports of the travellers and ethnographers of the late eighteenth and the nineteenth centuries dealt with 'shamanism' in Central Asia whereas not many sources referred to other methods of healing (Basilov 1992, 30-39). This fixation on shamanic rituals was noted by the researchers who criticize the tendency to neglect other important or even more central aspects of religious life of the local peoples like domestic cults and remembering dead ancestors in particular (Bellér-Hann 2001; DeWeese 1994; Kehl-Bodrogi 2008).

It is worth noting that such an approach coincided with the Russian imperial policies of those times. The Kazakh shaman's figure epitomized the wildness and backwardness of the native population. His healing methods were usually presented as 'tricks', ineffective and harmful (Afanas'eva 2008, 132-133). If not seen as sly deceivers, shamans were often described as individuals with serious mental disorders. That view was present in both biomedical approach and ethnographic accounts of those times and also persisted during the Soviet era (see, for example Alimkhanov 1978; for a critical discussion see Basilov [1992, 106-110]). ${ }^{6}$ In Michaels' opinion: 'This scholarship became the foundation for discrediting traditional medical practices, and for placing a monopoly of medical authority in biomedical practitioners' hands' $(2003,9)$. However, the attitude to other traditional forms of treatment was more ambivalent. Some doctors acknowledged that particular therapies might be effective and sometimes even better than methods of Russian medicine. ${ }^{7}$ It is clear, anyway, that critical assessments of shamans' and mullahs' healing practices as well as of other habits of the local peoples constituted a ground for the Russian 'civilizing mission' (Afanas'eva 2008, 133; Hohmann 2010a; Michaels $2003,35){ }^{8}$

The Soviet period brought about attempts to modernize the Central Asian region. Despite revolutionary slogans, those efforts, as many researchers note (for example, Michaels 2003; Roy 2000), were based on the ideological foundations laid during the Russian colonial period. Referring to traditional healing, Privratsky states: 'Russian scholarship treated the shaman as an obsolescent survivor of the nomadic cultural phase and thus encouraged the Soviet attack on the old healing arts' (2004, 570). Spiritual healers, together with mullahs, were treated as particularly harmful, although Soviet propaganda also presented other traditional medical practices as ineffective and even dangerous. However, despite severe persecutions of mullahs and shamans during the first decades of the new regime, traditional healing was not abandoned. Healers continued to work underground and then, towards the end of the Soviet Union, more and more openly. Michaels, using archival material and a survey conducted in Southern Kazakhstan, concludes that 'shamans and mullahs continued to serve the population, albeit in secret, throughout the Soviet era' $(2003,67)$. Indeed, my informants from Almaty often 
told me that it had been possible during Soviet times to find, if need be, a good, strong shaman through informal links.

\section{Baqsi and other spiritual healers in the context of medical pluralism in post-Soviet Kazakhstan}

I studied the path of the healer in the context of medical pluralism and the role of complementary medicine in post-Soviet Kazakhstan. The array of non-biomedical methods and techniques available to the people was very wide, from the local medical traditions of various ethnic groups, through Chinese, Tibetan and Indian 'great medical traditions', to many new or relatively new therapies borrowed from Russia, Ukraine and the West. I was interested in the reasons for the growing interest in such methods and for the official approval that, as I believe, justifies the use of the term complementary medicine in this context.

Whereas this stance diverges from the previous Soviet policy, it should be remembered that it was already in the $1970 \mathrm{~s}-80 \mathrm{~s}$, in the period of 'late socialism' and perestroika, that some kinds of non-biomedical therapies were approved. ${ }^{9}$ In particular, a new category of healers called ekstrasensy, whose treatment was based on the concept of bio-energy, became increasingly popular across the Soviet Union. These phenomena show that the relations between biomedicine and alternative/complementary medicine in the Soviet and post-Soviet conditions should not be viewed as so strikingly different. It could be reasonably argued that among the most important reasons for the rise in interest in non-biomedical healing in the last decades of the Soviet Union was the crisis of legitimacy, or even 'delegitimation' (Aronson 2007) of professional medicine, connected with the failing Soviet economy. The break-up of the Soviet Union exposed the weakness of the health-care system and brought about its further, dramatic deterioration in post-Soviet states. I agree with Brown and Rusinova (2002) and Aronson (2007) who wrote about the rejection of professional medicine in contemporary Russia, that the turn to alternative medicine is due mainly to the declining public trust in health-care institutions. However, other factors influencing the public interest and official attitude to non-biomedical treatments should also be taken into account.

The policy of Kazakhstan's government towards complementary medicine can be described as generally positive or even supportive. Some of its branches, labelled officially as 'traditional medicine' (for example, Chinese and Korean acupuncture, hirudotherapy [use of leeches] and homeopathy) have been incorporated into the health-care system; they are taught at several medical universities and at the Almaty Institute for the Advancement of Physicians. The other sector, which was defined as 'folk medicine', includes such diverse methods and practices as spiritual healing, herbalism, bone-setting and 'bio-energy therapy'. They have also been accepted, although their position seems less stable.

It is apparent that the collapse of the health-care system in the newly independent Republic of Kazakhstan influenced considerably the stance of the authorities who promoted non-biomedical methods and remedies as inexpensive and easily available. Yet the other important reasons for the governmental acceptance of Kazakh medical traditions were closely connected with the nation-building policy. What had earlier been viewed as 'survivals' that would disappear with the process of modernization became an important part of Kazakh cultural heritage. The various acts of Parliament 'About the Health of the Nation of the Republic of Kazakhstan' (of 1992, 1997 and 2003) stressed the role of folk medicine as a valuable complement to the health-care system. This approach was in keeping with the overall revalidation of the traditions of the titular nation, important for the legitimization of the new state. Similar processes were observed in other post-Soviet Central Asian countries, such as Uzbekistan (Hohmann 2007; Kehl-Bodrogi 2008) or Kyrgyzstan. 
At the same time the Ministry of Health of the Republic of Kazakhstan attempted to control and regulate the free market of healers, and to accredit their practices with reference to approved standards. The Republican Centre of Eastern and Contemporary Medicine in Almaty, founded in 1990 as the Centre of Folk Medicine, was entrusted with the task of training and licensing the healers. I will present these activities and the relations between biomedicine and spiritual healing in more detail in the last section of this article.

There are several categories of healers in Kazakhstan who appeal to the supernatural in their practice. First, shamans (Kaz. baqsl, Uyg. bakhshl) whose power is considered extraordinary and rare. Second, there are 'ordinary' spiritual healers (täwip) who usually combine spiritual healing with divination. Both categories resort to prayers from the Qur'an and supplications to Allah and saints in their practice. Mullahs (molda) also practise healing through the use of prayers.

Privratsky (2001, 194-195), in his book on the religious life of Kazakhs from the southern part of the country, proposed similar categorization of the Kazakh healers, but he only made brief references to the 'living Kazak shamans' and in most cases expressed a doubt over their shamanic identities. However, I met a few healers who called themselves baqsi and were recognized as shamans in the community; other researchers also mention shamans whom they approached during fieldwork in Kazakhstan (Bellér-Hann 2001, 2004; Grzywacz 2010; Jessa 2006a). I believe Privratsky's scepticism springs from his tendency to search for the 'authentic' baqsı. The Islamization of shamanic practices makes him call them 'faint images of archaic practice vaguely understood by Kazak healers themselves' (Privratsky 2001, 227). Here I adopt a local perspective on who is recognized as a baqsi and, on this basis, I cannot deny their presence among spiritual healers.

Shamans are thought to have special abilities and great powers thanks to the help of many powerful spirits. They have privileged connections with the spirit world; in the words of one of my informants 'they act as a bridge between earth and heaven'. Shamans may also have the gift of clairvoyance. Moreover, some characteristics of their séances such as trance states make them exceptional.

The 'ordinary' healers (täwip) are very popular - people ask them for help especially if they suspect that their health problems or misfortune have been caused by the evil eye (Kaz. köz tiyzu; Rus. sglaz) or witchcraft. They search for a renowned baqsi in the case of serious and persistent troubles, especially if they are attributed to the influence of evil spirits (jin) or the so-called porcha (Rus.), particularly harmful black magic.

The practices of spiritual healers generally follow traditional patterns. They have traditional utensils for expelling the evil spirits: the whip (qamshr) and the knife (plshaq). Those who practise divination use 41 stones or beans (qumalaq) for that purpose. In addition, the Qur'an and the rosary (täspi), signs of the Muslim identity of healers, form part of their equipment. Yet they borrow and assimilate some other methods and attributes, most eagerly those characteristic of ekstrasensy, like healing with 'bio-currents'. Hybridization is also seen in the 'pantheon of spirits' of contemporary healers who sometimes add to their helping spirits the saints and gods of other religions and even heroes of popular culture. (For similar examples on Buryat shamans see Humphrey [1999]). Despite a lack of sufficient data, it may be supposed that in more remote areas of the country hybridization of spiritual healing is not so marked. Healers in the city have a diverse clientele and they recognize that enrichment of the methods used may win them more popularity.

As I observed, spiritual healing based on belief in the world of spirits and their assistance in healing was popular in the Almaty of the 1990s among Kazakhs and other Turkic groups like Uyghurs or Tatars. Moreover, the patients of such healers were sometimes people of diverse ethnic origin, including Russians, Ukrainians or Germans. 


\section{'Shamanic illness' as the core experience in the making of a contemporary spiritual healer}

Although the term 'shamanic illness' is a concept favoured by researchers, perhaps the more suitable term would be the 'call of spirits', more commonly recognized by people on the ground. However, because of the long tradition of the use of the former term in scholarly literature, I preserve it and apply it here also to other spiritual healers whose initiation exhibits very similar traits to those of the shaman.

As I already mentioned, despite Soviet attempts to eradicate traditional Kazakh medicine, some healing rituals, including shamanic practices, continued. Nevertheless, a long period of militant atheism brought about a considerable disruption to the healing traditions, especially in the cities. With the hegemony of biomedicine and its discourse, the traditional meaning of the symptoms of 'shamanic illness' was generally forgotten. Signs that had been earlier identified by the people as the 'call of spirits' were attributed by medical doctors to mental disturbances. In other words, what had been previously connected with the realm of the supernatural was seized by biomedical discourse and classified as mental illness. This scientific discourse, which influenced a popular attitude, established the practice that in the case of such unusual symptoms doctors - if they could not find any organic disease - diagnosed the sufferer as mentally impaired.

However, since the beginning of the 1990s, when healers started to practise openly, the traditional notions of 'shamanic illness' have been gradually revived.

I heard stories from many practitioners about their path to becoming a healer which revealed the same general pattern. Their sufferings started suddenly, sometimes provoked by a traumatic event or by a visit to mazar - a place where a saint or ancestors are buried. The afflicted individuals described their anxiety and distress, frightening visions and dreams in which they usually saw old, bearded men clothed in white. They also experienced physical symptoms of illness, often severe, and doctors could not help them. Because of those disturbances and strange behaviour, such as sudden attacks of panic and hearing voices, their relatives as well as doctors suspected mental illness and such persons often underwent psychiatric treatment, to no avail. When, at last, somebody advised them to visit a healer, their sufferings became intelligible. It was made clear by the spiritual specialist that the sufferer was someone chosen by spirits, and that strange dreams and visions were in fact revelations (ayan $)^{10}$ of their departed ancestors' will. They wanted to pass the healing gift (darin) to their descendant who should accept this and become a healer since the only way to recover was to comply with the spirits' demand. Otherwise, not only would the disobedient person be severely punished, but her/his close relatives might suffer and even die as well. Narratives of the healers reported widely on the terrible pain and suffering they had experienced until they accepted the 'call of spirits'. Those 'initiation stories' were strikingly similar, although healers differed in age, sex, ethnic origin (Kazakhs, Uyghurs, Uzbeks, Tatars), social background and education. ${ }^{11}$

I will give a few examples. Bayan, a Kazakh woman from a poor family living in a small village near Turkistan, had been continually affected by the evil eye since her early childhood, and every time a mullah helped her with recitation of the Qur'an. When Bayan's brother died, near the end of the 1980s, she visited the mausoleum of a famous Central Asian saint, Ahmad Yasawi, in Turkistan. A pious woman who recited prayers near the tomb told her that she should start to heal people, otherwise her close relatives would die prematurely. Bayan was frightened. However, she did not follow that advice, even though old men whom she saw in her dreams demanded that she accepted their gift. It was only after a series of accidents and deaths of some other members of her family that she decided to embrace the path of the healer. I also talked to Katya, a 50-year-old Kazakh historian from Almaty whose abilities were uncovered 
by Dilya, a healer and clairvoyant from the Centre of Eastern and Contemporary Medicine. Katya was afraid herself that she was mentally ill and her husband confirmed her in that belief. However, several visits to the Centre completely changed her view and she decided to quit her job and start to apprentice to Dilya. ${ }^{12}$ It should be noted that apprenticeship also includes Islamic spiritual guidance of a neophyte.

Yet another Kazakh woman-healer and physician in her mid-50s, Tamara from Almaty, told me about her experience. At the beginning of the 1990s she developed strange symptoms - she had breathing difficulties at night and saw in her dreams a row of old men in white, repeating: 'You have to heal people.' Tamara did not understand that, and being afraid of having mental illness, went to a psychiatrist. However, her fears were not confirmed by the doctors nor were suppositions about a somatic illness. Then she met an acquaintance who had already begun working as a healer and they visited the Centre of Folk Medicine. After completing several courses of acupuncture, massage, astrology and learning the methods of Kazakh folk medicine, Tamara decided to combine them with biomedicine and started to work at the Centre. It is interesting in her case that although her path was more characteristic of urban eclectic practitioners, she received a traditional kind of blessing (bata: blessing for a new path, which was ritually given by a shaman) from a renowned, charismatic healer Umut apa (Mother Hope) who led a 'healing commune' near Pavlodar in Northern Kazakhstan.

An illustrative example is the case of an Uyghur bakhshl, Rakhilyam, living near Almaty, a woman in her early 50s then. As she told me, she had had such illness episodes twice. For the first time she was partially paralyzed, had convulsions and heard voices; sometimes a grimace suddenly twisted her face and she shouted involuntarily. She visited different medical specialists with no results. At last she was directed to a psychiatric clinic, but after a short stay there her sister took her to an old Uyghur shaman from the vicinity of Almaty. The shaman helped her, but - as Rakhilyam maintained - he did not reveal the truth about her abilities, because then, at the end of the 1980s, he was still afraid to talk about it. But when she visited the same shaman some years later complaining of strange symptoms again, he explained the meaning of her experiences. He revealed to Rakhilyam that she had 'shaman's blood': the shamanic gift offered by her ancestor spirits, which she was obliged to accept. When she decided to embrace the path of the shaman, she recovered entirely.

While in the past the call of spirits usually occurred in the period of adolescence, currently it often strikes a person of middle age who lived many years unaware of her/his potential. It is not surprising, if we consider the disruption to shamanic traditions. However, in the case of Mahira, Rakhilyam's daughter, the traditional pattern of an early revelation was observed. She had been offered the shamanic and clairvoyance gift when she was only 17, but since she did not feel ready, the spirits waited until her middle 20s. This motif of postponement, waiting until the future shaman feels prepared for her/his duties, is well known from the sources on shamanism in Central Asia. (See Goršunova [2000, 192-194] on a shaman-woman Khadicha from Osh region, Kyrgyzstan).

Some other cases of 'shamanic illness' experienced by present-day Kazakh healers are described by Grzywacz (2010, 26-28). Kehl-Bodrogi, who did insightful research into Khorezm healers (2008, 201-220), notices the importance of 'initiatory illness' and dream revelations. She points out: "Although the "illness-pattern" in the case of healing is not exclusive to Central Asia and Siberia, in that context it does appear to be a particular cultural imperative, as the Khorezmian case also illustrates' (Kehl-Bodrogi 2008, 215-216).

The strength of the phenomenon of the call of spirits in contemporary Central Asia needs careful consideration. It cannot simply be attributed to the 'revival of tradition'. What seems particularly interesting here is the fact that 'shamanic illness' appears as a most immutable element of the local healing traditions. I think that this may be explained primarily by the importance of 
commemorating the spirits of ancestors, thoroughly discussed by Privratsky (2001). Noticeably, beliefs concerning the close ties between the living and the dead, and the influence of the latter on the lives of their descendants continued during Soviet times as did domestic rituals such as 'emitting of the smell' (of hot oil) for the ancestral spirits (Jessa 2006a, 363; Privratsky 2001, 128-133) which show great similarity across Central Asia (Kehl-Bodrogi 2008, 126-127). It is just these beliefs that underlie 'shamanic illness'. An important factor is that the 'call of spirits' appears crucial for the legitimization of healers, which I will discuss in the next section.

Such illness is a prerequisite for becoming a spiritual healer, but the role of training under a master seems to be quite important today. I observed several of Rakhilyam's healing séances and some of them revealed potential healers among the patients. In one case a bakhsh her patient, a young Uyghur girl named Elmira, that her ailment was caused by the evil eye, which had already affected the girl in childhood. The girl was a 'spiritual person' (that is, someone with close connections with spirits), thus she was particularly vulnerable. The main point of the ritual was to purify Elmira. Next, the shaman explained that the spirits had offered two gifts to Elmira. First, the ability to heal people with prayers; second, the help of particular spirits who would come to her in the shape of birds. The girl seemed shocked by that revelation. Rakhilyam tried to convince her patient to obey the spirits' will, telling her that otherwise she would not recover. Rakhilyam also spotted future healers during other séances. An important part of the procedure of revealing candidates was pointing to the ancestors: shamans or other spiritual healers, or mullahs. Usually a person seems not to remember such predecessors and it is the experienced healer who makes her/him recall that. Being lineal kin of a 'spiritual person' definitely reinforces the claims of future practitioners, although it is the ancestor spirits who are believed to appoint someone among their living descendants. This follows the traditional pattern of the healer's legitimacy.

Similar examples of identification of future healers by the experienced ones are given by the researchers working in Central Asia (Bellér-Hann 2001, 79; Goršunova 2000, 201). According to Kehl-Bodrogi, a shared dream in which the future master and apprentice are 'shown' to each other is the precondition for the establishment of apprenticeship in healing in Khorezm (2008, 219). Such cases were also reported by some of my Kazakh informants, but rather with reference to the further development of healers. ${ }^{13}$

It was often stressed that in Central Asia, apprenticeship did not have an important place in the career of the shaman (Basilov 1992, 119-121; Toleubaev 1997, 199). However, in postSoviet Kazakhstan, experienced senior healers play a crucial role in appointing and giving legitimacy to spiritual healers. Their authority revives and legitimizes the traditional meaning of strange symptoms and sufferings. It is the healer's diagnosis, presented as an expression of ancestor spirits' will, that starts a candidate's initiation and it is the healer's duty to make a person chosen by spirits accept the call as well as to assist her/him in this way. The relations between the master and the neophyte can be described as apprenticeship, although the actors themselves tend to belittle these ties and stress the main role of spirits in the paths of a healer (cf. Bellér-Hann 2001, 88-89).

An interesting phenomenon is the visible dominance of female healers, both in Kazakhstan and in other parts of Central Asia. In the case of the Kazakhs, it is justified to call this a gender shift, as previously the Kazakh shamans were mostly male. However, there are also men among contemporary spiritual (and other) healers, albeit in a minority. ${ }^{14}$ The researchers tend to explain the feminization of healing by the diminishing prestige of these practices. It is suggested that women, as the most marginalized, took over what was abandoned by the men. According to a different view, the 'domestication' of shamanic practices during the Soviet times greatly contributed to this shift (for the discussion see Kehl-Bodrogi [2008, 198-199]). While the domestication argument seems reasonable and accords with the evidence of the significance of 
domestic rituals, performed by women, to religious continuity, I would not agree with the marginalization thesis. As my research indicates, healing can be the source of quite a good income, and there is an intense rivalry among the healers in this lucrative market (cf. Bellér-Hann 2001, 96). I would rather connect the interest of women in healing with their increasing agency. Some of the woman-healers whom I met achieved a high position, overtaking men in their families, and gained the respect of their community. Even if they were not all so successful, entering the 'healing profession' not only gave them some income, but also liberated them, at least partly, from other social obligations and familial relationships of dependence.

Local healing traditions in Kazakhstan have been strengthened by their close connections with Islamic religiosity. I wish to point out that spiritual healing, together with pilgrimages to sacred places or wearing amulets, is locally perceived in Kazakhstan and other parts of Central Asia as a truly Muslim practice. Many authors concur that it is an important component of what is called 'Muslimness' in the region (Grzywacz 2010; Kehl-Bodrogi 2008; Privratsky 2001; Rasanayagam 2006). This term, as Kehl-Bodrogi puts it, 'describes religion as it is lived rather than as it is defined by the theologians'. (2008, 84). I would add that there was evidence from Kazakhstan about some informal Islamic organizations, like Aq jol ('Pure Way'), established around 1997, whose main purpose was the revitalization of Muslim religiosity at the grass-roots level. It is significant that at the core of their activities were group séances of ritual purification and healing performed by charismatic spiritual leaders-healers. During Aq jol meetings, experienced healers revealed the potential healers with special abilities; they also organized collective pilgrimages to mazars (Jessa 2006a, 2006b). In that way they actively contributed to the spread of ideas about the intercession of ancestor spirits in healing, as well as to the return to the previous communal character of the healing séances.

I can only briefly touch upon the complex issue of the 'official' Islamic discourse on local 'Muslimness', including spiritual healing. Most of the scholarship on Central Asian Islam denies a simplistic dichotomy of 'official' and 'unofficial' or 'popular' Islam. Nevertheless, researchers (Jessa 2006b; Omelicheva 2011) attest to the shift in the meaning of 'unofficial' Islam in the discourse of the governing regimes, the term 'now deployed in relation to the alleged threat of religious "extremism" and "fundamentalism" (Omelicheva 2011, 245). Although the attitude of the Muslim Spiritual Directorate of Kazakhstan (muftiyat) towards 'popular' expressions of Islam is generally critical, the stance of the government to what is officially now called 'traditional' Islam may be characterized as positive, since it has been appropriated as closely associated with Kazakh ethnic and cultural identity. However, Omelicheva gives a detailed description of the on-going 'securitization' of Islam in Kazakhstan 'under the guise of combating terrorism and religious extremism' $(2011,251)$. This process may influence the attitude of the government to some local expressions of Muslim religiosity, and the criminalization of Aq jol in 2009 can serve as evidence of such changes.

Finally, the diagnosis that refers to the traditional idea of the 'call of spirits' instead of the label 'mentally ill' has important social consequences. Such a person is given credentials to become a healer, not sent to a psychiatrist. Moreover, spiritual healers themselves are treated as specialists who can help people with mental disorders. The acceptance of traditional illness etiologies (the evil eye, black magic, punishment by spirits, and so on) enhances the popularity of spiritual healers, especially in the case of chronic disturbances that are difficult to explain in biomedical terms. Kassymbekova (2003) writes about turning to spiritual healers in Southern Kazakhstan and Kyrgyzstan when mental illness occurs: a common practice reinforced by a lack of trust in mental-health facilities. According to the psychiatrists from Kyrgyzstan, from the local Kyrgyz point of view, 'an initial psychotic episode is usually considered a "spiritual emergence" and a patient generally has to visit a number of traditional healers before a psychiatrist takes care of him or her' (Molchanova et al. 2008, 68). Molchanova and Altpaeva (2008) 
maintain that the trust in folk healers who offer their help to people with mental disorders is continually growing in contemporary Kyrgyzstan. The data presented by Grzywacz (2010) also testifies to the increase in the popularity of healers in Kazakhstan in the 2000s.

\section{Spiritual healing, biomedicine and the state}

As mentioned earlier, the 'discourse of tradition' has been at least partially accepted in the official - governmental and biomedical - attitude to 'folk' medicine. It was expressed in the activities of the Republican Centre of Eastern and Contemporary Medicine in Almaty founded under the auspices of the Ministry of Health. Its main purpose was to institutionalize traditional medicine, to vet traditional practices in order to differentiate 'the wealth of ancient national knowledge' from what was perceived as harmful and connected with the practices of 'charlatans'. This attitude was also characteristic of the physicians working at the Centre whose important obligation was to monitor the healers.

Bureaucratic legitimization procedures initiated by the Centre started with a preliminary assessment of the mental health of the prospective healers carried out by a special commission with the participation of a psychiatrist. According to the Centre's statistics, between 1991 and 1996 as many as 1781 candidates out of 2508 were rejected, 1434 (80.5\%) of them because of 'psychiatric disorders' (Khabieva 1997, 9). However, in the opinion of the physicians from the Centre, the 'call of spirits' should be clearly differentiated from mental illness. Not only did they accept it as a part of the Kazakh tradition, but some of them had had the same experiences, as in the case of the deputy director of the Centre, Tamara, a doctor and a healer. As I could observe, various complementary therapies were often practised by medical doctors themselves, and that certainly influenced their approach to traditional healers. ${ }^{15}$

An approved person had to work for two months at the Centre under strict supervision of a doctor and the next stages of her/his career depended on the medical assessment of the results. Candidates were obliged to attend courses at the school for healers opened at the Centre, which provided training in some specialties (folk phytotherapy, bone-setting, bio-energy treatment, parapsychology, astrology and 'cosmic medicine') together with a short course on basic anatomy. The examination commission included, besides some members of the senior staff of the Centre, a representative of the Ministry of Health and a psychiatrist appointed by the Ministry. After passing final examinations, healers got certificates and obtained the right to work legally. However, they were also obliged to pay for a licence and to repeat the procedure every two (later, three) years, a requirement which was not met by many practitioners. Formally, dealing with four types of diseases was forbidden to healers: psychiatric problems; cancer; infectious diseases; and health problems that needed surgical interventions. Besides, healers might be punished ${ }^{16}$ for various improprieties, like performing mass séances of treatment or 'using wild methods'. What methods were considered 'wild' depended on the decision of doctors; in the opinion of the head of the division of contemporary medicine it was, for example, beating the patient with a whip, often used in traditional healing. ${ }^{17}$ Officials from a special unit at the Centre were given the right to monitor healers from the whole country (although the Centre established its branches in several other oblast main cities), yet the controls were not particularly effective and many unlicensed practitioners worked in the cities and even more so in the villages.

The procedure of bureaucratic accreditation was also applied to spiritual healers, who - if successful - got a certificate of teopsikhoterapevt ('theopsychotherapist'). All in all, between 1991 and 2000 about 1000 practitioners received certificates of 'a professional folk healer of the Republic of Kazakhstan' in one of four specialties: 'theopsychotherapist'; phytotherapist; bone-setter; and 'bio-energy therapist'. In the case of spiritual healers, obtaining a certificate was, however, often treated as a rather costly formal requirement and sometimes even an 
obstacle in the way of the healer. Rakhilyam, the shamaness, maintained that it was her great mistake that she had decided to undergo this procedure, because her helping spirits were discontented with that and hindered her further progress. An interplay of different factors could be observed in healers' decision making. On the one hand they wanted to get a more stable position in the market and, in the cities, the opportunity to work in the centres of complementary medicine; yet on the other, both for them and their patients, traditional sources of legitimacy remained the most valued. ${ }^{18}$ And the 'call of spirits' was definitely the main constituent of traditional legitimacy, which was also admitted by the physicians from the Centre.

The attitude of those medical specialists who are rather positive about the value of traditional spiritual healing may be illustrated by the statements of a psychiatrist delegated by the Ministry of Health who had worked for several years as a member of the certification commission at the Centre. This Kazakh woman, a professor of psychiatry, expressed her doubts about mentalhealth assessments and argued for a very careful approach. In her opinion, someone who was diagnosed with schizophrenia might sometimes be 'entirely normal' and apparently deviant behaviour might simply prove the extraordinary abilities of that person, for example, clairvoyant powers. She also maintained that, albeit rare, such special abilities were real, and her experiences at the Centre had significantly changed her viewpoint as a psychiatrist, although it was not shared by the majority of her colleagues from the psychiatric clinic.

According to Kassymbekova:

Professional medical personnel admit that most patients at psychiatric hospitals only arrived after their psychiatric illnesses had reached an advanced stage. Doctors and nurses may not have much faith in religious psychology, but they often shunt 'no-hope cases' off to healers. They view taeyips as a cultural tradition that people in Shymkent and other communities created, protect, and are comforted by. Some even suggest that taeyips should consider getting formal training, so they can offer more professional help. $(2003,4)$.

Latypov (2010), in his article about the transformation of mental-health care in Tajikistan, ponders the possibility of accommodation of some local beliefs and practices related to spirits and health, in view of the crisis of Tajik psychiatry. He concludes:

The healers whom we interviewed in Tajikistan were willing to work in partnership with psychiatrists, but in the words of one of them, "healers do not have close links with psychiatrists because most doctors do not appreciate alternative[s to bio]medicine yet.' (Latypov 2010, 444).

It is worth stressing that some psychiatrists from neighbouring Kyrgyzstan have already started collaboration with spiritual healers, arguing that traditional healing has unquestionable psychotherapeutic value (Adylov 1999, 2007; Molchanova and Aĭtpaeva 2008; Molchanova et al. 2008). My research in Kazakhstan shows that a similar tendency was present there in the second half of the 1990s, partly motivated by the poor quality and availability of psychiatric care. Data about further developments in this field would be of great value.

\section{Conclusions}

In this article I attempted to show that traditional discourse on spiritual healers' initiation - the call of the spirits - has been revived in post-Soviet Kazakhstan. This also applies to many other aspects of traditional healing. As Bellér-Hann rightly argues, 'despite the disruptions and changed circumstances, the claim of modern Central Asian healers to local antecedents (and thereby to tradition) is not unfounded' $(2001,74)$.

I tried to explain the reasons for the government's acceptance of 'folk' medicine, including spiritual healing, which mainly lies in its interest in the resurgence of Kazakh culture and history, important to the legitimacy of the newly independent state. This context was definitely conducive to the revival of spiritual healing. This phenomenon cannot be treated as 'invented tradition' 
but rather as 'adapted tradition', in Babadzan's (2000) terms. Similar processes were discussed by Hohmann (2010b) in relation to Uzbekistan, in her study on the strategies of reconstruction of the national identity with the use of traditional medicine based on the heritage of Avicenna. She also points out that this is an instrumental 'rehabilitation' of tradition, rather than invention of tradition. In that case, however, official recognition of traditional medicine is limited only to the so-called 'great tradition' of Avicenna, while in Kazakhstan the reference to 'national heritage' led to the rehabilitation of the entire body of 'folk' medicine.

I focused on 'shamanic illness' and the changing attitude to the 'call of spirits' because it seems exceptional in the sense that it appears the most resilient, the core experience of the spiritual healer which has strikingly uniform traits. I argued that the significance of the remembrance of the dead among the Kazakh and other Turkic peoples contributed to the revival of beliefs about the 'call of spirits'. The strength of this tradition has, in my opinion, helped to restore the previous meaning of the call of spirits in popular discourse and influenced biomedical (mainly psychiatric) discourse, especially, but not exclusively, in the institutional context of the Republican Centre of Eastern and Contemporary Medicine.

The example of 'shamanic illness' is illustrative, because it reveals how political, economic and social transformations influenced the valorization of traditional knowledge, perceptions of illness and healing at the popular and official level. Although in general the position of complementary medicine in Kazakhstan seems stable, the current situation suggests that official policy towards 'folk' medicine may change along with the attempts to develop the state according to modern standards.

\section{Acknowledgements}

I would like to thank the anonymous reviewers for insightful comments and constructive suggestions.

\section{Notes}

1. I use the term 'spiritual healers' in reference to those practitioners who appeal to spirits (of ancestors and saints) or God in their activities.

2. The first, short version of this paper was presented at the conference 'Healing Paradigms and the Politics of Health in Central Asia' organized by the Global Health Research Center of Central Asia at Columbia University in New York on 8 April 2011.

3. However, there is evidence of the existence of female shamans (see Basilov 1992, 38, 55; Garrone 2000, 138-143; Michaels 2003, 29).

4. Mental illness was commonly ascribed in Central Asia to the influence of evil spirits which were expelled in the course of the shaman's or mullah's healing. See for instance a detailed report by Divaev (1899) of the healing séance of the Kyrgyz (that is, Kazakh) baqsi who exorcized jinns from the mentally ill patient ('hit by jinns').

5. For detailed descriptions of 'shamanic illness' among Turkic and other Central Asian peoples see Dyrenkova (1930) and Basilov (1992, 106-142). It is not, of course, an emic term - the Kazakh usually speak about being pressed or smothered by ancestor spirits. Privratsky quotes the saying: 'The ancestor spirits "burn" in the Kazak healer' $(2004,572)$.

6. I will not refer further to the well known but discredited and now irrelevant arguments developed long ago by ethnologists and historians of religion about the sources of 'shamanism' in mental illness of the shaman (see Eliade 1951).

7. A good and often cited example is the local treatment of rishta (the parasitic worm Dracunculos medinensis which causes dracunculosis) confirmed as an effective method by Russian physicians (Kushelevskiî 1891, 148-149; Palkin 1967, 478-482; cf. Hohmann 2010a, 328-329). A well-known fact is that Russian medicine adopted Kazakh kumiss (kımız) - fermented mare's milk - for treatment of tuberculosis and other lung diseases (Afanas'eva 2008, 130-132; Michaels 2003, 34; Palkin 1967, $528-533)$. 
8. Researchers who write about the introduction of Russian medicine in Central Asia generally agree that it served as an instrument for political legitimization of the Empire (Afanas'eva 2008; Hohmann 2010a; Michaels 2003). However, Afanas'eva $(2008,116)$ warns against direct application of analytical models like Said's Orientalism to the history of the Russian Empire and criticizes Michaels for overgeneralizations.

9. For example, various forms of acupuncture (called in Russ. iglorefleksoterapiya). According to the review of the health system in Kazakhstan (Kulzhanov and Rechel 2007, 108), those methods were formally recognized in the Soviet Union as early as in 1977 and permitted as a part of medical rehabilitation.

10. See Louw (2010) for discussion on the significance of dreams as divine revelations in Kyrgyzstan.

11. There are no apparent differences in the initiation experiences of the healers of different ethnic (Turkic) backgrounds, whereas some elements of healing practices differ; for example, Uighur healers use willow twigs for hitting the patients.

12. This is characteristic of the traditional and also contemporary healer's way that s/he is obliged to concentrate on spiritual development and remove all obstacles in this path. Therefore it is better to divorce if the spouse does not accept this mission than disappoint the spirits.

13. Similarly, healers could be called in their dreams to visit a particular mazar in order to get a blessing from the saint connected to that sacred place.

14. Unlike the Uzbeks of Khorezm, where Kehl-Bodrogi did not meet any male folbin (healer) (KehlBodrogi 2008, 199).

15. As the doctors from the Centre told me, it was estimated that, all in all, until the year 2000, several thousand physicians in Kazakhstan had completed courses of traditional medicine (Chinese and Korean medicine, hirudotherapy, manual therapies) and perhaps quite a large number of them used those methods in practice. Besides, some doctors combined biomedicine with the methods of 'folk' medicine or healing with bio-energy.

16. Formally, they could be imprisoned for one to three years. In practice, inspectors fined such unlicensed healers and tried to persuade them to pass the procedures of official accreditation.

17. Applying a whip was not forbidden - it could be used for expelling evil spirits, but not for beating the patients. However, many healers working outside the Centre continued traditional methods.

18. Similarly, in Kyrgyzstan and Uzbekistan, as Pelkmans (2005) and Kehl-Bodrogi (2008) showed, spiritual healers were not interested in getting official diplomas and relied entirely on traditional legitimacy.

\section{References}

Adylov, D. U. 1999. Psikhiatricheskie i psikhoterapevticheskie aspekty tselitel'stva v Kyrgyzstane [Psychiatric and Psychotherapeutic Aspects of Healing in Kyrgyzstan]. Bishkek.

Adylov, D. 2007. "Healing at Mazars: Sources of Healing, Methods of Curative Impact, Types of Healers and Criteria of Their Professional Qualifications." In Mazar Worship in Kyrgyzstan: Rituals and Practitioners in Talas, edited by G. Aitpaeva, A. Egemberdieva and M. Toktogulova, 377-394. Bishkek: Aigine Research Center.

Afanas'eva, A. 2008. "'Osvobodit' ot shaŭtanov i sharlatanov': diskursy i praktiki rossiǔskoŭ meditsiny v kazakhskor stepi v XIX veke ['Liberate from Devils and Charlatans': Discourses and Practices of Russian Medicine in the Kazakh Steppe in the XIXth Century]." Ab Imperio 4: 113-150.

Alimkhanov, Zh. A. 1978. "Psikhopatologicheskie yavleniya v shamanizme [Psychopatological Phenomena in Shamanism]." In Ocherki po istorii narodnor mediciny Kazakhstana [Notes on the History of Folk Medicine of Kazakhstan], edited by T. Sh. Sharmanov and B. A. Atchabarov, 65-76. Alma-Ata: Institut kraevoŭ patologii Minzdrava KazSSR.

Aronson, P. 2007. "Rejecting Professional Medicine in Contemporary Russia." Vestnik, The Journal of Russian and Asian Studies 8 May. (Accessed January 15, 2012). http://www.sras.org/rejecting professional_medicine_in_contemporary_russia.

Babadzan, A. 2000. "Anthropology, Nationalism and 'The Invention of Tradition'." Anthropological Forum 10 (2): $131-155$.

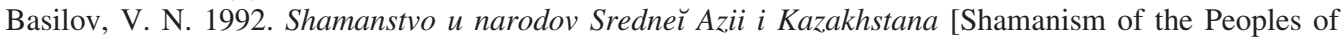
Central Asia and Kazakhstan]. Moskva: Nauka.

Bellér-Hann, I. 2001. "Rivalry and Solidarity among Uyghur Healers in Kazakhstan.” Inner Asia 3: 73-98.

Bellér-Hann, I. 2004. "The Micropolitics of a Pilgrimage." In Central Asia on Display. Proceedings of the 7th Conference of the European Society for Central Asian Studies, 2000 Vienna, edited by G. Rasuly-Paleczek and J. Katschnig, 325-338. Münster: Lit Verlag. 
Brown, J., and N. Rusinova. 2002. "“Curing and Crippling': Biomedical and Alternative Healing in PostSoviet Russia." Annals of American Academy of Political and Social Science 583: 161-170.

DeWeese, D. 1994. Islamization and Native Religion in the Golden Horde: Baba Tükles and Conversion to Islam in Historical and Epic Tradition. University Park: Pennsylvania State University Press.

Divaev, A. A. 1899. "Iz oblasti kirgizskikh verovaniı̌. Baksy kak lekar' i koldun (Ėtnografičeskiǐ ocherk) [From the Kyrgyz Beliefs. Baksy as a Doctor and Sorcerer (Ethnographic Notes)]." Izvestiya Obshchestva Arkheologii, Istorii i Etnografii pri Imperatorskom Kazanskom Universitete 15 (3): 307-341.

Dyrenkova, N. P. 1930. "Poluchenie shamanskogo dara po vozzreniyam turetskikh plemen [Reception of the Shamanic Gift according to the Views of Turkic Tribes]." Sbornik Muzeya Antropologii $i$ Ėtnografii 9: 267-291.

Eliade, M. 1951. Le chamanisme et les techniques archaïques de l'extase. Paris: Payot.

Garrone, P. 2000. Chamanisme et islam en Asie Centrale. La baksylyk hier et aujourd'hui [Shamanism and Islam in Central Asia: Baksylyk Yesterday and Today]. Paris: Libraire d'Amérique et d'Orient, Jean Maisonneuve Successeur.

Goršunova, O. V. 2000. "Tyazhkoe bremya 'shamanskogo dara': sud'ba sovremennoŭ ferganskoŭ bakhshi [A Heavy Burden of 'Shamanic Gift': the Fate of a Contemporary Bakhshi from Fergana]." In Shamanskiŭ dar. K 80-letiyu doktora istoricheskikh nauk Anny Vasil'evny Smolyak [The Shamanic Gift. On the 80th Anniversary of Dr. Anna Vasil'evna Smolyak's Birth], edited by V. I. Kharitonova, 191-204. Moskva: Institut ètnologii i antropologii im. N.N. Miklukho-Maklaya.

Grzywacz, Z. 2010. "Traditional Kazakh Medicine in Change.” Turkic Studies [online] 2. (Accessed November 20, 2011). http://www.turkicstudies.amu.edu.pl/turkic_studies_2_2010.pdf.

Hohmann, S. 2007. "Les 'médecins-tabib', une nouvelle catégorie d'acteurs thérapeutiques en Ouzbékistan post-soviétique? [Doctors-Tabib: A New Category of the Therapeutic Actors in Post-Soviet Uzbekistan?]." Autrepart 42: 73-90.

Hohmann, S. 2010a. "La médecine moderne au Turkestan russe: un outil au service de la politique colonial [Modern Medicine in Russian Turkestan: a Tool at the Colonial Politics Service]." In Une colonie pas comme les autres?, edited by S. Gorshenina and S. Abashin, 319-351. Paris: Editions Complexes.

Hohmann, S. 2010b. "National Identity and Invented Tradition: The Rehabilitation of Traditional Medicine in Post-Soviet Uzbekistan." The China and Eurasia Quaterly Forum 8 (3): 129-148.

Humphrey, C. 1999. "Shamans in the City." Anthropology Today 15 (3): 3-10.

Jessa, P. 2006a. "Aq Jol Soul Healers: Religious Pluralism and a Contemporary Muslim Movement in Kazakhstan." Central Asian Survey 25 (3): 359-371.

Jessa, P. 2006b. "Religious Renewal in Kazakhstan: Redefining 'Unofficial Islam'.” In The Postsocialist Religious Question: Faith and Power in Central Asia and East-Central Europe, edited by Ch. Hann, and the "Civil Religion" Group, 169-190. Berlin: Lit Verlag.

Kassymbekova, B. 2003. "Turning to the Taeyip." Transitions Online 27 Nov. (Accessed November 2, 2011). http://www.tol.org/client/article/11110-turning-to-the-taeyip.html.

Kehl-Bodrogi, K. 2008. "Religion is Not so Strong Here." Muslim Religious Life in Khorezm after Socialism. Berlin: Lit Verlag.

Khabieva, T. Kh. 1997. “Rol' Respublikanskogo nauchno-prakticheskogo tsentra vostochnoŭ i sovremennoŭ

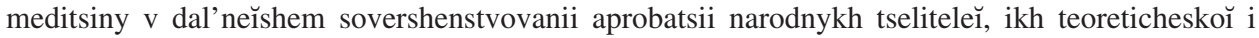
prakticheskor podgotovke [The Role of the Republican Scientific-Practical Centre of Eastern and Contemporary Medicine in the Advancement of Folk Healers, their Theoretical and Practical Preparation]". In Traditsionnaya i narodnaya medicina [Traditional and Folk Medicine] (materialy I Respublikanskoŭ nauchno-prakticheskoŭ konferentsii, Almaty, 1-3 oktyabrya 1997 g.). Vol. 1, edited by E. A. Abylkasymov and A. V. Chemeris, 6-10. Almaty: Kazakhskiŭ gosudarstvennyı̆ meditsinskii universitet.

Kulzhanov, M., and B. Rechel. 2007. "Kazakhstan: Health System Review." Health Systems in Transition 9 (7): 1-158.

Kushelevskiı̆, V. I. 1891. Materialy dlya medicinskoŭ geografii i sanitarnago opisaniya Ferganskoŭ oblasti [Materials for Medical Geography and Description of Sanitary Conditions in Fergana Valley]. Vol. 2-3, Novyı̆ Margelan.

Latypov, A. 2010. "Healers and Psychiatrists: The Transformation of Mental Health Care in Tajikistan." Transcultural Psychiatry 47 (3): 419-451.

Louw, M. E. 2010. “Dreaming up futures: Dream Omens and Magic in Bishkek." History and Anthropology 21 (3): $277-292$. 
Michaels, P. A. 2003. Curative Powers. Medicine and Empire in Stalin's Central Asia. Pittsburgh: University of Pittsburgh Press.

Molchanova, E., and G. Altpaeva. 2008. "Ritualy v kyrgyzskoj kul'ture i vozmozhnosti ikh ispol'zovaniya v psikhologicheskol praktike [Rituals in Kyrgyz Culture and the Possibilities of their Implementation in Psychological Practice]." Academic Review of American University in Central Asia 5 (1): 75-87.

Molchanova, E. S., Sh. Horne, E. A. Kim, V. I. Ten, N. A. Ashiraliev, G. A. Aitpaeva, and D. E. Pokhilko. 2008. "Status of Counseling and Psychology in Kyrgyzstan." Academic Review of American University in Central Asia 5 (1): 57-72. (Accessed November 3 2011). http://elibrary.auca. $\mathrm{kg}: 8080 /$ dspace/bitstream/123456789/234/1/Molchanova\%20tc_2008_1.pdf.

Omelicheva, M. Y. 2011. "Islam in Kazakhstan: A Survey of Contemporary Trends and Sources of Securitization." Central Asian Survey 30 (2): 243-256.

Palkin, B. N. 1967. Ocherki istorii mediciny i zdravookhraneniya zapadnoŭ Sibiri i Kazakhstana v period prisoedineniya $k$ Rossii (1716-1868) [Notes on the History of Medicine and Health Care in Western Siberia and Kazakhstan during the Period of Incorporation to Russia (1716-1868)]. Novosibirsk: Zapadno-Sibirskoe Knizhnoe Izdatel'stvo.

Pelkmans, M. 2005. "Clairvoyants and Healers in Kyrgyzstan. New Guises and Uses of an Old Profession." Paper presented at the workshop organised by Institute of Ethnology and Cultural Anthropology, Adam Mickiewicz University in Poznań and Max Planck Institute for Social Anthropology in Halle: Popular Religiosity after Socialism, May 28-30, in Czerniejewo, Poland.

Penkala-Gawecka, D. 2002. "Korean Medicine in Kazakhstan: Ideas, Practices and Patients." Anthropology and Medicine 9 (3): 315-336.

Penkala-Gawęcka, D. 2009. "Kazakh Medical Traditions in Present-Day Kazakhstan: Locally Rooted, Regionally and Globally Flavoured." In Proceedings of the 9th Conference of the European Society for Central Asian Studies, 2005 Cracow, edited by J. Pstrusińska and T. Gacek, 272283. Newcastle upon Tyne: Cambridge Scholars.

Privratsky, B. 2001. Muslim Turkistan: Kazak Religion and Collective Memory. Richmond: Curzon Press.

Privratsky, B. 2004. "Kazak Shamanism." In Shamanism: An Encyclopedia of World Beliefs, Practices, and Culture, edited by M. N. Walter and E. J. Neumann Fridman, 569-573. Santa Barbara, CA: ABCCLIO.

Rasanayagam, J. 2006. "Healing with Spirits and the Formation of Muslim Selfhood in Post-Soviet Uzbekistan." Journal of the Royal Anthropological Institute 12: 377-393.

Roy, O. 2000. The New Central Asia: The Creation of Nations. London: I.B. Tauris Publishers.

Sharmanov, T. Sh., and B. A. Atchabarov, eds. 1978. Ocherki po istorii narodnoŭ mediciny Kazakhstana [Notes on the History of Folk Medicine of Kazakhstan]. Alma-Ata: Institut kraevor patologii Minzdrava KazSSR.

Toleubaev, A. T. 1997. "Nekotorye obshchie vyvody po shamanstvu kazakhov [Some General Remarks on the Kazakh Shamanism]." In Istoriya issledovaniŭ kul'tury Kazakhstana [History of the Studies on the Culture of Kazakhstan], edited by E. Z. Kažibekov, 193-203. Almaty: Qazaq universiteti. 